\title{
Acryl in
mijn mond
}

\section{Mocht je plotseling een snijtand verliezen en ter vervanging een plaatje nodig hebben, dan was het afgelopen jaar niet de beste tijd om de prothese te laten maken en plaatsen. Het overkwam mij.}

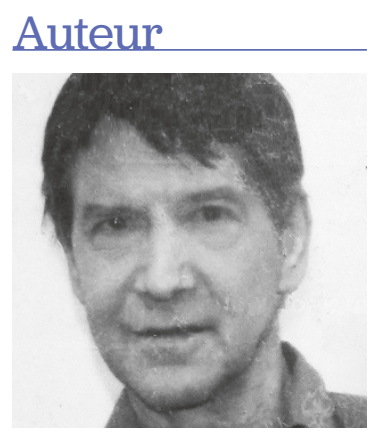

Dr. Frank Heynick (New York) is onder andere medisch-dentaal historicus. Voordat hij in Groningen tot doctor in de geneeskunde promoveerde, studeerde hij industriële vormgeving, geschiedenis, taalwetenschap en psychologie.
Medio maart vorig jaar stond ik in Brooklyn midden in de nacht op de stoep een stuk pizza te eten. De kaas was zeer kleverig en trok mijn stifttand - de vervanger van mijn snijtand linksboven - uit de wortel. Aan de stift zat een stuk wortel vast. Blijkbaar zat er een breuk in de wortel.

Ik maakte een afspraak met mijn tandarts, Rudolph Weinstein. Toen ik aan het eind van de middag bij de praktijk aankwam, was de deur echter op slot. Ik belde aan en dr. Weinstein sprak tot mij via de intercom. Hij vertelde dat de praktijk tot nader bericht gesloten zou zijn. De coronapandemie was dus in volle gang. Nu moest ik voor onbepaalde tijd zonder snij- tand verder. In de dagelijkse praktijk maakte dat niet veel uit. Het eten van bijvoorbeeld een appel ging goed. Het uitspreken van Engelse klanken zoals de labiaaldentale ' $f$ ' van ferry en de ' $v$ ' van very ging nog wel. De linguaaldentale 'th'-klank, zowel stemhebbend en stemloos (the thing), kon met de punt van de tong en één snijtand gemaakt worden, of desnoods (als beide snijtanden ontbreken) met de alveolaire rand.

Het vervelende was het uiterlijk. Rondlopen zonder een van je snijtanden is 'geen gezicht'. Maar in dit opzicht was de coronapandemie - de oorzaak van deze vervelende toestand ook een zegen. Je moest toch bijna elke dag thuisblijven. Als je eens in de week een uurtje naar buiten ging om boodschappen te doen en een mondkapje moest dragen, dan maakte een missende snijtand niet veel uit.

Mijn situatie was dus niet spoedeisend. Tandarts Weinstein behandelde voorlopig uitsluitend noodgevallen. In de zomer werd het virus tijdelijk minder gevaarlijk. De werkwijze van
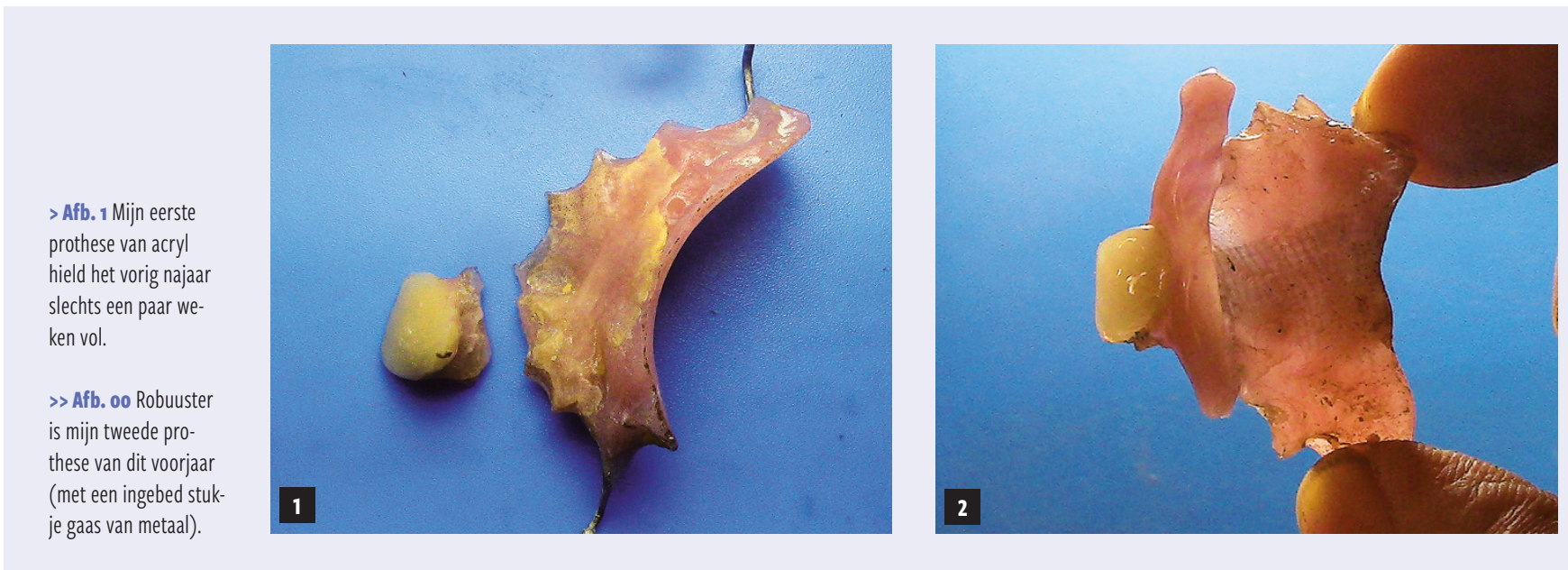
Weinstein werd minder stringent. Op basis van een afdruk van mijn mond liet hij de tandtechnici een 'flipper' maken - een integraal plaatje met een kunsttand uit acryl en (bijna onzichtbaar) twee haakjes van metaal voor om de twee hoektanden (zie afbeelding $\mathbf{1}$ ). Ik kon af en toe zonder mondkapje naar anderen glimlachen. Dat maakte me blij.

Deze gelukkige toestand bleek helaas van korte duur. In oktober zat ik popcorn te eten. In een van de stukjes zat iets hards. Toen brak de tand af. Het coronavirus was In de koude 2020-maanden weer gevaarlijker geworden. Dit betekende dat ik (omdat ik tot een hoog-risicogroep behoor) nog een halfjaar zonder linkerbovensnijtand zou hebben moeten leven.

In het voorjaar van dit jaar kreeg ik mijn eerste en tweede covid-inentingen. Tijd voor een nieuwe prothese. Tandarts Weinstein liet (zonder extra kosten voor mij) een stevigere uitvoering maken (zie afbeelding 2). De kwetsbare verbinding tussen het plaatje en de kunsttand was nu breder en versterkt met een stukje gaas van metaal. Hij was ook iets dikker (voor de occlusie vijlde Weinstein de bovenkant van de ondertanden een klein beetje af). Het plaatje heeft een iets andere vorm dan de vorige versie. De prothese blijft mede door zuigkracht goed zitten. En zonder haakjes.

\section{PLEXIGLAS}

Aan wie had ik deze mooie prothese van acryl te danken, historisch gezien?
Rond 1930 ontwikkelden scheikundigen in Engeland en Duitsland de verbinding polymethylmethacrylaat. Deze stof was doorzichtig en kon, evenals glas, als ruiten toegepast worden. Vergeleken met glas was acryl minder hard en dus minder bestendig tegen krasjes. Acryl was op hoge temperaturen ook brandbaar. Maar acryl was daarnaast taaier, lichter, flexibeler en gemakkelijker te snijden (ook in onregelmatige vormen) en te verlijmen.

Het grootste voordeel van acryl ten opzichte van glas had met veiligheid te maken. In de Tweede Wereldoorlog gebruikten zowel de geallieerden als hun tegenstanders acryl (onder de handelsmerken Plexiglas, Perspex en Lucite), vooral voor de doorzichtige delen van vliegtuigen (zie afbeelding 3). De verwondingen bij de bemanning als het acryl door een kogel of bomscherf werd getroffen, waren gemiddeld minder ernstig dan bij ruiten van glas, dat harder en scherper is en meer versplintert. In de loop der jaren werd doorzichtig acryl toegepast in onder andere aquaria. Acryl heeft ook een belangrijke invloed op de kunst gehad, als materiaal voor transparante beeldjes. Ook werd acrylverf een alternatief voor olieverf. Acrylverf op waterbasis droogt snel op (en is dan vochtbestendig); daardoor kan een kunstenaar zonder lang te hoeven wachten een nieuwe laag aanbrengen. In de jaren zestig werden de acrylschilderijen van beroemde kunstenaars als Andy Warhol, Roy Lichtenstein en Mark Rothko heel populair. (Zelf heb ik veel geprofiteerd van acryl in mijn kunstwerk. Zie afbeelding 4.)

\section{LENS}

En op medisch gebied dan?

Tijdens de Tweede Wereldoorlog merkte de Engelse oogarts Sir Harold Ridley dat het afweersysteem nauwelijks reageerde op splintertjes acryl in de ogen van piloten van Spitfires waarvan de ruiten kapotgeschoten waren. Met splintertjes van glas was het anders. Deze biocompatibiliteit van acryl motiveerde $\mathrm{dr}$. Ridley om intra-oculaire kunstlenzen van acryl te implanteren. Ook hele kunstogen werden van acryl gemaakt, evenals de lenzen van brillen - lichter en minder breekbaar dan glas, maar wel gevoeliger voor krasjes. Acrylverbindingen zijn vervolgens onder andere als zachte filler voor cosmetische chirurgie gebruikt. In de tandheelkunde werden tijdens de Tweede Wereldoorlog proeven gedaan met vullingen van acryl, maar de resultaten waren niet bevredigend. Als materiaal voor dentale protheses bleek acryl echter uitstekend te werken, dankzij de biocompatibiliteit, het lichte gewicht, de taaiheid en het vermogen om in allerlei tinten en texturen vervaardigd en afgewerkt te kunnen worden.

Tenslotte dit: Afgelopen periode vanaf voorjaar 2020 was niet de beste tijd voor tandtechnici en voor de leveranciers van acryl aan tandtechnische laboratoria. Maar voor de producenten van grote acrylplaten was het een geweldige tijd. Denk aan de spatschermen in elke winkel en de doorzichtige wanden van al de tenten op de trottoirs hier in New York.

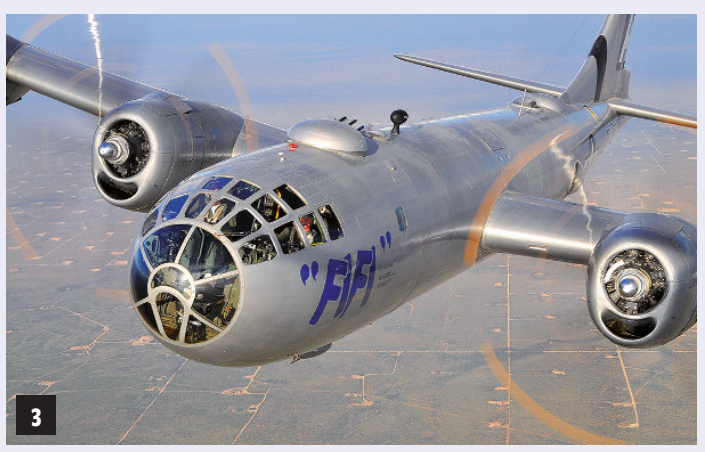

A Afb. 3 Veel doorzichtig acryl in de Amerikaanse B-29 bommenwerper die in 1944-1945 in groten getale werd geproduceerd. (Bron: airpowersquadron.org)

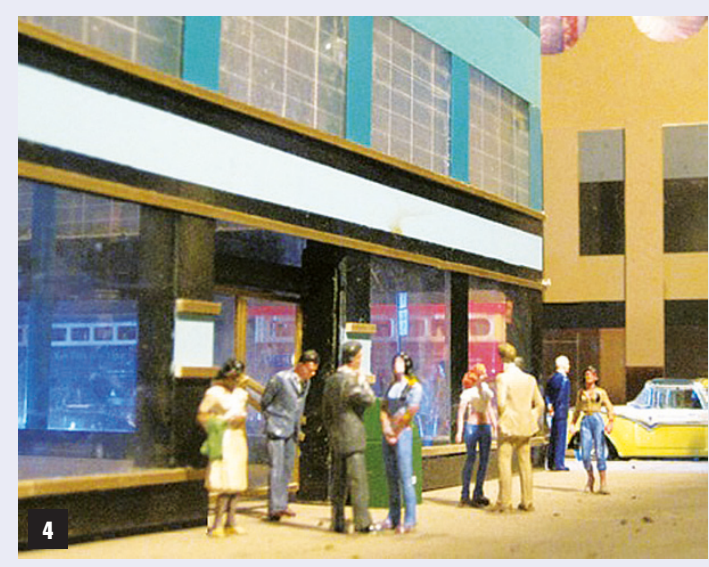

$<$ Afb. 4 Detail van mijn modelstad Mini-Gotham. Ik maakte de vele wolkenkrabbers uit platen doorzichtig acryl, spoot vervolgens met acrylverf delen van iedere verdieping in verschillende kleuren en voegde details van plastic of hout toe. 